\title{
Semi-coking of oil shale of the Leningrad deposit
}

\author{
I.V. Litin, M.Yu. Nazarenko, and S.N. Saltykova
}

Department of Chemical Technology and Energy Processing, Faculty of mineral raw material processing, Saint-Petersburg Mining University, Saint-Petersburg, Russia

\begin{abstract}
Recently, there has been a growing global interest in processing low-grade types of solid fuels, such as oil shale. In the near future, the role of solid fuels in the country's fuel and energy balance is expected to increase, primarily due to their large reserves. Based on this, this work evaluates the semi - coke obtained by semi-coking low-grade types of solid combustible fossils-oil shale of the Baltic basin (Leningrad deposit). The influence of process parameters (temperature and holding time) on the physical and chemical properties of shale semi-coke was studied experimentally. Based on the data obtained, it is concluded that the obtained samples of semi-coke from oil shale and brown coal can be used as a substitute for coke in various industries and the national economy.
\end{abstract}

\section{Introduction}

The development of the fuel and energy complex entails a direct increase in energy consumption and the development of fundamentally new types of resources. World energy consumption per capita in 1950 increased by 2 times compared to the beginning of the century, then doubled again by 1975. In 1980, the average per capita energy consumption was already 2.4 tons of conventional fuel, and currently the total consumption of conventional fuel is estimated in billions of tons. For example, at the moment, the consumption of oil is more than 400 billion tons of conventional fuel per year, of gas is more than 300 bln tons, of coal more than 2000 bln tons, etc. $[1,2,3,4,5]$.

The potential component of the reserves of organic fuels is about $90 \%$ of solid raw materials, such as oil shale, peat, brown and hard coals, anthracite, etc. However, the main share of solid fuels is used as energy raw materials, and for the production of various products, for example, metallurgical coke, high-quality raw materials are used (coking coals, etc.) [6].

Recently, there has been a growing global interest in processing low-grade types of solid fuels, i.e., - shale oil [7,8.9.10]. Based on the above, this work is devoted to the study of the process of semi-coking of low-grade solid natural energy carriers, e.g., oil shale in order to increase the efficiency of using this type of raw material.

Oil shale contains kerogen, i.e., transformed organic matter from higher plants and simple organisms. In appearance, oil shale is a solid odorless material ranging in color from yellow to brown. It is characterized by low calorific value, enrichment with hydrogen, and a high content of ash $(42 \div 60) \%$; the oil shale ash also has a high content of $\mathrm{CaO}$. 
The amount of low-grade raw materials (oil shale) potential resources are huge and in Russia, this equals approximately to 700288.85 million tons. One of the largest Baltic basin deposits is located in the Leningrad field (Table 1), Russian Federation. Large reserves of these raw materials and yearly growing energy consumption manifest the need to solve the problems associated with their processing [11,12,13,14,15].Energy consumption every year indicate the need to solve the problems associated with their processing[11,12,13,15].

Table 1.The deposits of oil shale in Russia.

\begin{tabular}{lcc}
\hline \multicolumn{1}{c}{ Basin } & Reserves of oil shale, mln.t. & Reserves of shale oil, mln.t. \\
\hline Baltic ( Leningrad deposit) & 10246.7 & 1386.2 \\
Timan-Pechora & 4888.0 & 351.4 \\
Vychegodskiy & 58105.8 & 4590,0 \\
Central & 59.6 & 5.4 \\
Volzhskiy & 25822.4 & 2805.5 \\
South Ural & 47.55 & 2.8 \\
Olenek & 380000.0 & 19000.0 \\
Sinskaya-Boomski & 220000.0 & 5500.0 \\
Just & 700288.85 & 33701.8 \\
\hline
\end{tabular}

Oil shale is widely used in many countries (the USA, Estonia, China, etc.) and is an important potential raw material for the fuel and energy and chemical industries. The main method of oil shale processing, which holds a unique position among low-grade raw materials, is thermal processing; currently, an extensive experience has been accumulated in this area (processes: Haloter, Enefit Estonia; Alberta Tasiuk, Australia; "Petrosik", Brazil; "Fushun", China; "Lurgi-Rurgaz", Germany; "Union" the USA, and others). The full-scale use of oil shale is restrained due to the unresolved technical problems associated with the formation of large amounts of waste (up to $50 \mathrm{wt} \%$ compared to the initial amount of shale), for the storage of which it is necessary to allocate vast territories. Moreover, the oil shale is less energy-intensive than other fossil fuels $[12,13,15]$.

\section{Materials and methods}

We consider oil shale from the Baltic Basin of the Leningrad field: moisture is $2.0 \%$, ash con- tent is $50.5 \%$, volatile content is $41.43 \%$, and absolute density is $1643 \mathrm{~kg} / \mathrm{m} 3$.

Preparation of raw materials is carried out using:

- Particle size analyzer AS 200 Control (classification in different fractions of the feedstock);

- Laboratory disk eraser LDI-65 (grinding the shale to a fraction of less than 125 microns);

- Grinding polishing machine Mr-1V (sample preparation for analysis on optical devices).

The moisture content of the oil shale semi-coke is determined in a drying chamber, in accordance with the state standards GOST 27589-91 and GOST 33503-2015. A 2-g sample taken from semi-coke of piece size $<0.125 \mathrm{~mm}$ is dried at $105 \pm 5^{\circ} \mathrm{C}$.

The ash content is determined in accordance with state standard GOST 22692. A 2-g sample is roasted in a muffle furnace at $815 \pm 10^{\circ} \mathrm{C}$ and held to constant mass at specified temperature. The yield of volatiles is determined in accordance with state standards GOST 
22898 and GOST R 55660. A 1-g sample in a porcelain crucible with a ground-glass lid is heated in the absence of air at $815 \pm 10^{\circ} \mathrm{C}$ for $7 \mathrm{~min}$ in a muffle furnace. The yield of volatiles $(\%)$ is calculated from the mass loss of the sample, after subtracting the moisture content.

The porosity of the oil shale semi-coke is determined by analysis of the actual and apparent density. The actual density is determined by weighing the coke sample in the air and in pycnometric liquid, while the apparent density is determined by weighing the water displaced by the sample, in accordance with the state standards GOST 22898 and GOST $10220-82$

The mineral composition of the oil shale and oil shale semi-coke is studied on a DRON 6 X-ray diffraction instrument, equipped with an X -ray tube (with a cobalt anode) and a secondary graphite monochromator. The diffraction patterns are analyzed by means of PDWin 4 software and the ICPDS international card library. The Rietveld method is used for quantitative determination of the phases. The chemical composition of the oil shale and oil shale semi-coke was analyzed using the Epsilon 3 PANalitical energy dispersion Xray fluorescent spectrometer. The sample mass is $3 \mathrm{~g}(<0.125 \mathrm{~mm}$ fraction).

The change in oil shale and oil shale semi-coke mass on heat treatment is investigated in the SETARAM Instrumentation calorimetric system in the range $(25 \div 1000)^{\circ} \mathrm{C}$ at a heating rate of $18^{\circ} \mathrm{C} / \mathrm{min}$.

The semi-coking process is carried out on a laboratory installation, which is shown in Fig. 1. Temperature control is provided by means of a muffle furnace 4 with two independently operating thermocouples 2 and 3 for controlling the temperature in the furnace and the temperature in the reactor. A u-shaped tube 8 with calcined calcium chloride is designed to capture traces of moisture. Drexel 9 flasks are used to absorb ammonia and are filled with a solution of $1 \mathrm{~mol} / \mathrm{l}$ sulfuric acid with a methyl orange

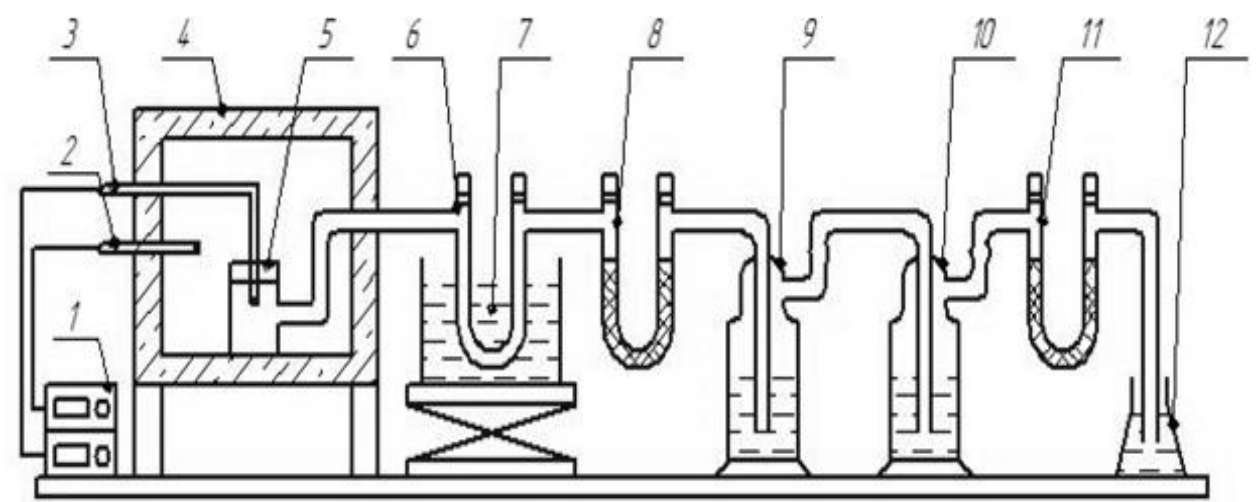

indicator. Flask 10 is designed to capture carbon monoxide and is filled with a solution of sodium hydroxide (30\%). The U-shaped tube 11 is filled with activated carbon to capture raw benzene.

1-temperature control; 2,3-thermal converters; 4-muffle furnace; 5-reactor with gas phase discharge; 6-condenser; 7-cooling capacity; 8-calcium chloride tube; 9,10-Drechsel flasks; 11-carbon tube; 12 the capacity of the receiver gas

Fig. 1. Developed laboratory installation for semi-coking of low-grade types of solid fuels.

Parameters of the process of semi-coking of low-grade types of solid combustible fossils: raw oil shale, brown coal with a particle size of $(2 \div 4) \mathrm{mm}$; sample weight $-20 \mathrm{~g}$. (provides filling of $2 / 3$ of the reactor); exposure time when entering the mode $-3,5$, and 8 
hours; operating temperature $-(450 \div 470)^{\circ} \mathrm{C}$ (mode I) and $(510 \div 520)^{\circ} \mathrm{C}$ (mode II); muffle furnace heating speed $-4.76^{\circ} \mathrm{C} / \mathrm{min}$; reactor heating speed $-6.11^{\circ} \mathrm{C} / \mathrm{min}$.

The $(510 \div 520)^{\circ} \mathrm{C}$ temperature and exposure time of 8 hours are the base parameters for the oil shale semi-coking process; they were selected based on the modern literature data. In this work we investigated the impact of temperatures varying from $(510 \div 520)^{\circ} \mathrm{C}$ to $(450 \div 470)^{\circ} \mathrm{C}$ and exposure times from 3 to 8 hours per product for the optimization of semi-coking process and reduction of operational expenditures.

\section{Results}

The average material balance of the process of semi-coking of oil shale from theLeningrad deposit is shown in Table 2.

Table 2.Material balance of the process of semi-coking of Leningrad deposit oil shale.

\begin{tabular}{|c|c|c|c|c|c|}
\hline \multicolumn{2}{|c|}{ Coming } & \multicolumn{4}{|c|}{ Expenditure } \\
\hline Material & Mass, $\mathrm{g}$ & $\%$ & Material & Mass, $\mathrm{g}$ & $\%$ \\
\hline \multirow{3}{*}{ Oil shale } & & & Semi-coke & 13.0 & 65.0 \\
\hline & 20.0 & 100.0 & Oil & 4.2 & 21.0 \\
\hline & & & Gas & 2.8 & 14.0 \\
\hline Total & 20.0 & 100.0 & Total & 20.0 & 100.0 \\
\hline
\end{tabular}

The characteristics of the resulting oil shale semi-coke are shown in Table 3; the following indications are used here: moisture content (W), volatile yield (V), ash content (A), apparent density $(\rho)$, actual density $(d)$, porosity $(P)$.

Table 3.Quality indicators of semi-coke from the oil shale of the Leningrad field.

\begin{tabular}{|c|c|c|c|c|c|c|c|}
\hline & & \multicolumn{6}{|c|}{ Characteristics } \\
\hline & & $\mathrm{W}, \%$ & $\mathrm{~V}, \%$ & $\mathrm{~A}, \%$ & $\rho, \mathrm{g} / \mathrm{cm}^{3}$ & $\mathrm{~d}, \mathrm{~g} / \mathrm{cm}^{3}$ & $\mathrm{P}, \%$ \\
\hline Oil shale & - & 2.00 & 41.43 & 50.50 & 1.64 & 1.24 & 24.34 \\
\hline \multirow{3}{*}{$\begin{array}{l}\text { Semi-coke, } \\
\text { mode I } \\
(450 \div 470){ }^{\circ} \mathrm{C}\end{array}$} & $3 \mathrm{~h}$ & 1.15 & 41.50 & 46.30 & 1.71 & 1.39 & 18.50 \\
\hline & $5 \mathrm{~h}$ & 0.81 & 38.09 & 54.20 & 1.94 & 1.52 & 21.65 \\
\hline & $8 \mathrm{~h}$ & 0.78 & 37.05 & 57.56 & 1.98 & 1.53 & 22.91 \\
\hline \multirow{3}{*}{$\begin{array}{l}\text { Semi-coke, } \\
\text { mode II } \\
(510 \div 520){ }^{\circ} \mathrm{C}\end{array}$} & $3 \mathrm{~h}$ & 1.08 & 42.80 & 51.56 & 1.71 & 1.39 & 18.67 \\
\hline & $5 \mathrm{~h}$ & 0.99 & 40.59 & 52.60 & 1.96 & 1.49 & 23.67 \\
\hline & $8 \mathrm{~h}$ & 0.98 & 38.98 & 53.95 & 1.99 & 1.53 & 22.78 \\
\hline
\end{tabular}

Based on the data presented in Table 3 , the yield of volatiles at temperature mode II $(42.80 \% ; 40.59 \% ; 38.98 \%)$ is higher than in mode I $(41.50 \% ; 38.09 \% ; 37.05 \%)$. Under the used temperature conditions, the material becomes more compact and, as a result, the density increases. For mode I, the density increases from $1.64 \mathrm{~g} / \mathrm{cm}^{3}$ to $1.98 \mathrm{~g} / \mathrm{cm}^{3}$, and for mode II, to $1.99 \mathrm{~g} / \mathrm{cm}^{3}$. In addition, in the second mode, the source material loses its mass more actively (confirmed by the data of the yield of volatility) and, consequently, the ash content increases.

The chemical compositions of the oil shale of the Leningrad deposits and oil shale semi coke are shown in Table 4.

Table4. The chemical composition. 


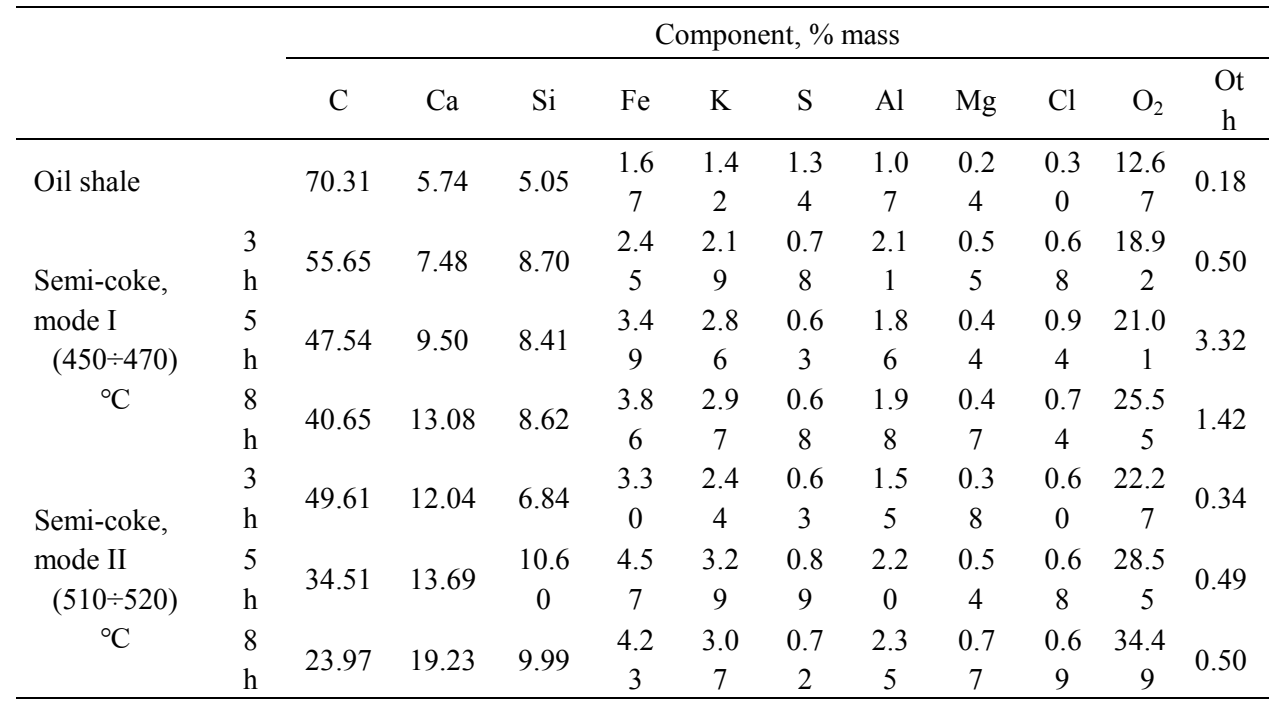

In addition to the elements presented in Table 4 , the presence of such elements as $\mathrm{Ni}$ $(0.22 \%), \mathrm{Cu}(0.01 \%)$, and $\mathrm{P}(0.02 \%)$ was also detected in small quantities.

Based on the conducted research, it was determined that these elements were present in the initial sample of oil shale in the form of such minerals as $(\mathrm{Ca}(\mathrm{Fe}, \mathrm{Mg})(\mathrm{SiO} 3) 2)-3.70 \%$, $(\mathrm{CaSiO} 3)-2.91 \%,(\mathrm{CaAlSiO} 3 \mathrm{O} 10(\mathrm{OH}) 2)-2.91 \%,(\mathrm{Al} 2 \mathrm{O} 3)-0.75 \%,((\mathrm{Ca}, \mathrm{Fe}) \mathrm{SiO} 3)-$ $2.99 \%,(\mathrm{FeO})-5.97 \%,(\mathrm{FeS} 2)-5.01 \%,(\mathrm{CaCO} 3)-14.36 \%,(\mathrm{SiO} 2)-10.82 \%$, and after the semi-cokingprocess were converted to various silicates of $\mathrm{Ca}$ and $\mathrm{Al}$, for example $(\mathrm{Ca} 2 \mathrm{~A} 12 \mathrm{SiO} 3 \mathrm{O} 10)-2.91 \%,(\mathrm{Ca}-\mathrm{SiO} 3)-2.90 \%,(\mathrm{Ca}(\mathrm{Fe}, \mathrm{Mn}) \mathrm{SiO} 6)-3.3 \%,(\mathrm{CaSiO} 3)-$ $2.95 \%,(\mathrm{SiO} 2)-22.72 \%$.

Based on the results of thermogravimetric analysis of the initial sample of oil shale (Figure 2), it can be noted that the mass reduction occurs at 4 stages: stage 1 occurs in the temperature range from $17^{\circ} \mathrm{C}$ to $260^{\circ} \mathrm{C}$; stage 2 - from $260^{\circ} \mathrm{C}$ to $540^{\circ} \mathrm{C}$; stage 3 - from $540^{\circ} \mathrm{C}$ to $645{ }^{\circ} \mathrm{C}$; stage $4-$ from $645{ }^{\circ} \mathrm{C}$ to $939^{\circ} \mathrm{C}$. At the same time, exothermic peaks are observed at $351{ }^{\circ} \mathrm{C}$, which can be explained by the release of resin, and at $499^{\circ} \mathrm{C}$, when the evaporation of the released resin occurs. One endoscope at a temperature of $715^{\circ} \mathrm{C}$ indicates the process of decomposition of the mineral component of the sample of oil shale

Analysis of the sample (Figure 3), which was subjected to a semi-coking process for 5 hours at $(450 \div 470)^{\circ} \mathrm{C}$ showed 3 stages of mass drop: stage 1 was from $17{ }^{\circ} \mathrm{C}$ to $270^{\circ} \mathrm{C}$, stage $2-$ from $270^{\circ} \mathrm{C}$ to $525^{\circ} \mathrm{C}$, stage $3-$ from $525^{\circ} \mathrm{C}$ to $760^{\circ} \mathrm{C}$. At the same time, there is a weakly expressed exothermal point at a temperature of $360^{\circ} \mathrm{C}$, which shows a small amount of residual resins. A pronounced exothermal point at a temperature of $507{ }^{\circ} \mathrm{C}$ characterizes the evaporation of the resin not re- leased in the process of semi-coking. The endoscope at a temperature of $696^{\circ} \mathrm{C}$ shows the de- composition of the mineral component of the sample.

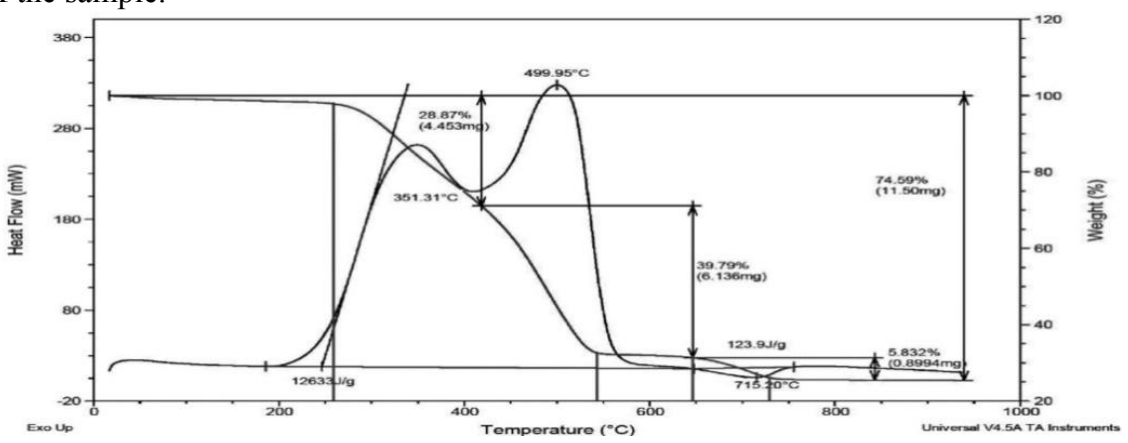


Fig. 2.Thermogravimetry of the initial sample of oil shale.

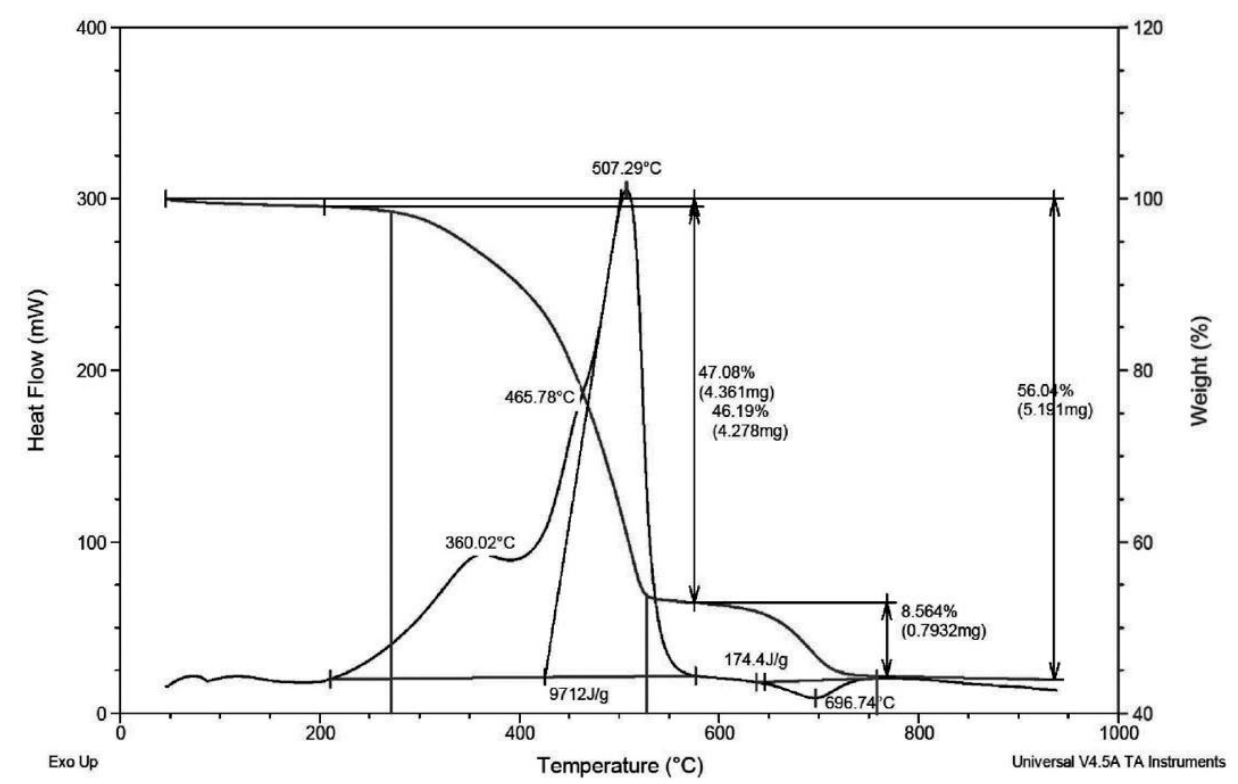

Fig. 3.Thermogravimetry of a sample of oil shale after semi-coking at $(450 \div 470){ }^{\circ} \mathrm{C}$ for 5 hours.

\section{Conclusions}

Samples of semi-coke were obtained from oil shale with several sets of characteristics. Oil shale semi-coke, mode 1: temperature $(450 \div 470)^{\circ} \mathrm{C}$, exposure time $(3,5,8$ hours), humidity $(1.15 \div 0.78) \%$, yield of volatile substances $(41.50 \div 37.05) \%$, ash content $(57.56 \div 46.30) \%$, actual density $(1.71 \div 1.98) \mathrm{g} / \mathrm{cm} 3$, apparent density $(1.39 \div 1.53) \mathrm{g} / \mathrm{cm} 3$, porosity $(18.50 \div 22.91) \%$; mode 2 : temperature $(510 \div 520)^{\circ} \mathrm{C}$, exposure time $(3,5,8$ hours), humidity $(1.08 \div 0.98) \%$, volatile matter yield $(42.8 \div 38.98) \%$, ash content $(51.56 \div 53.95) \%$, actual density $(1.71 \div 1.99) \mathrm{g} / \mathrm{cm} 3$, apparent density $(1.39 \div 1.53) \mathrm{g} / \mathrm{cm} 3$, porosity $(18.67 \div 23.67) \%$.

X-ray fluorescence and thermo gravimetric analyses of oil shale and obtained samples of oil shale semi-coke were performed. The carbon content in the initial sample was $70.31 \%$, with an increase in the holding time and temperature, a decrease to $23.97 \%$ occurred at mode $2(510 \div 520)^{\circ} \mathrm{C}$ and exposure time of 8 hours.

\section{Discussion}

Teams of authors from Jordan, Estonia, China and Ukraine have been exploring the process of semi-coking for the effect of process parameters on the physical and chemical properties of products. They also say that that it is necessary to raise the problem of semi-coking of low-grade carbon materials in more detail.

Researchers from the Institute of Geology of the National Academy of Sciences of Azerbaijan, Aliyev A. A., Abbasov O.R., Agayev A.M. investigate the properties and composition of oil shale from various deposits and waste from their thermal processing. The authors deal with properties and composition of oil shale for employing it as an alternative energy source in Azerbaijan. Haddad R. H., Ashteyat A.M., Lababneh Z. K from 
the Jordan University of Science and Technology are engaged in the problem of oil shales ash composition. They are interested in producing composites based on ash $[16,17]$.

The kinetics of thermal destructive processing of oil shale from different deposits has been investigated by Y. Xie , H. Xue, H. Wang, Z. Lie, C. Rang. They also modify a theory about atmosphere influence to the thermal processing of shale $[18,19]$.

The oil shale complex processing is the subject of special interest in different foreign countries; that's why this problem is relevant nowadays. The results of analyses of oil shale semi-coke samples, such as ash content, yield of volatile substances, actual and apparent density, porosity and humidity are in good agreement with the data and hypotheses of above-named authors. The results of X-ray fluorescence and thermo gravimetric analysis shows a decrease in the carbon content from $70.31 \%$ to $23.97 \%$ with an increase in the exposure time and temperature, and make a contribution to the current field of research.

Acknowledgments: this work was carried out as part of the State Assignment "Development of scientific foundations of innovative technologies for processing heavy hydrocarbon raw materi- als into environmentally friendly motor fuels and new carbon materials with controlled macro- and micro structural organization of mesophase". The study was conducted with the involvement of the laboratory base of the Center for Collective Use of Saint Petersburg Mining University.

\section{References}

1. N.S. Pechuro, Chemistry and technology of synthetic fuel and gas.(Moscow: Chemistry, 2020)

2. R.Yu.Feshchenko, I.I.Beloglazov, V.Yu. Bazhin, Deep conversion and metal content of Russian coals, Eurasian mining. 2:28-32 (2016)

3. V.Yu. Bazhin, Changes in thermal plasticity of low grade coals during selective extraction of metals. Zapiski GornogoInstituta. 220:578-581(2016).

4. R. Y.Feshchenko,O.O.Erokhina,V.L.Ugolkov,M.Y.Shabalov,V.V. Vasiliev Thermal analysis of coal ash. Coke and Chemistry,1:17-22(2017)

5. A.M.Askhabov,O.V. Kotova, Horizons of applied mineralogy. Proceedings of the Russian mineralogical society. 148 (6):117-125(2019)

6. T.E. Igoeva, Kyzyl ash dump as a source of adverse impact on the environment. Siberian Economic Journal,6: 885-892(2010).

7. A.M. Gerasimov, Thermo chemical processing of various carbon-containing raw materials in mixtures with oil shale. Coke and Chemistry,5:31-35. (2012).

8. Zh. K. Kairbekov, Thermo catalytic processing of brown coal and oil shale of the Kenderlyk deposit. Fundamental Research,9-4:924-926(2012).

9. O.M. Saether, The chemistry and mineralogy of waste from retorting and combustion of oil shale, Geological society special publication,236: 263-284.(2004).

10. Yu. A. Strizhakova, Ways of processing oil shale into chemical products. Chemistry of solid fuel,2: 86-90.(2006).

11. J. Ancheyta HYDRO-MPC technology for heavy oil refining. Notes of the Mining Institute, 224: 229-234.(2017).

12. M.Yu. Nazarenko, N.K.Kondrasheva, S.N. Saltykova, Surface reactivity of fuel shales from the Baltic basin. Coke and Chemistry,59 (5): 196-199.(2016).

13. M.G. Rudina, Handbook of oil shale processing. (Leningrad: Chemistry,1988). 
14. O.S. Zubkova, A.I.Alekseev, M.M. Zalilova, Research of combined use of carbon and alumi- num compounds for wastewater treatment. Izv. Vyssh. Uchebn. Zaved. Khim. Khim. Tekhnol. [Russ.J. Chem. \& Chem. Tech.].63 (4): 86-91(2020).

15. Q.Wang, J.Bai, J.Ge, Y.Z.Wie, S. Li, Geochemistry of rare earth and other trace elements in Chinese oil shale. Oil shale31 (3): 266-277(2014)

16. A.A.Aliyev,O.R.Abbasov,A.M. Agayev, Mineralogy and geochemistry of oil shale in Azerbaijan: classification, paleo-weathering and maturity features. Visnyk of V.N. Karazin Kharkiv National University, series "Geology. Geography. Ecology”.50,11-21 (2019)

17. R.H.Haddad, A.M.Ashteyat, Z.K. Lababneh, Producing geopolymer composities using oil shale ash. Structural Concrete. Journal of the Fib.20(1),225-235(2019).

18. Y. Xie, Kinetics of isothermal and non-isothermal pyrolysis of oil shale. Oil Shale.28(3),415-424(2011)

19. L-M. Raado, Oil shale ash based stone formation: hydration, hardening dynamics and phase transformations. Oil Shale.31(1),91-101(2014) 